\title{
WOJNA SPRAWIEDLIWA I WOJNA ŚWIĘTA: RAZ JESZCZE
}

\begin{abstract}
Streszczenie. Artykuł omawia argumenty Pawła Włodkowica, polskiego filozofa/teologa z XV wieku, dotyczące wojen etycznie usprawiedliwionych (ius ad bellum). Autor opowiada się za przyjęciem twierdzenia Włodkowica, zgodnie z którym rozum naturalny wyznacza granice dla uzasadnionych działań zbrojnych, a w szczególności zakazuje wszczynania wojen świętych, takich jak krucjaty Zakonu Krzyżackiego, wykluczając tym samym również wojny prowadzone przez współczesnych bojowników dżihadu. Zakazuje on także prowadzenia operacji militarnych wspieranych przez bojowo nastawionych rzeczników ideologii świeckich.
\end{abstract}

Słowa kluczowe: wojna sprawiedliwa, święta wojna i dżihad, uzasadniona i nieuzasadniona interwencja zbrojna

1. Wstęp. 2. Powrót do debaty na temat świętej wojny. 3. Argumenty uczestników świętej wojny.

4. (Religijna) obrona rozumu naturalnego. 5. Przeciw zwolennikom krucjat świeckich.

\section{WSTĘP}

Celem niniejszego eseju jest upamiętnienie dzieła Pawła Włodkowica, a także rozważenie szeregu kwestii, o których pisał - kwestii pilnych i nabrzmiałych zarówno przed sześciuset laty, jak i w chwili obecnej. Muszę jednak rozpocząć od kilku zastrzeżeń. Nie jestem badaczem średniowiecza i z całą pewnością nie jestem specjalistą w zakresie pism myślicieli Kościoła Katolickiego. Przeczytałem angielski przekład dzieł Włodkowica w redakcji Ludwiga Ehrlicha, ale, biorąc pod uwagę styl jego wywodów i nieustanne usiłowania, by powoływać się na poglądy wcześniejszych autorytetów, nie potrafię powiedzieć, na ile był on myślicielem oryginalnym. Nie posiadam też wystarczającej wiedzy na temat politycznych aspektów władzy papieskiej, Soboru w Konstancji czy też historii Polski w XIV i XV w., 
by jednoznacznie rozstrzygnąć, jak wiele potrzeba było odwagi, by przedstawiać argumentację, którą zawarł on w swoich pismach. Rozprawa Włodkowica Ad Aperiendam (1416) zawiera jednak kilka znakomitych wersów, których zapamiętanie chciałbym zalecić czytelnikom zanim przystąpię do omówienia poglądów krakowskiego uczonego. Włodkowic zapowiada, że zamierza rozważyć prawomocność władzy cesarza i papieża, której zakres jest, jego zdaniem, w obu przypadkach ograniczony - zapowiada zatem zajęcie stanowiska, które z dużym prawdopodobieństwem nie spodoba się zwolennikom żadnej z tych władz. Zamierza to zrobić, jak pisze, ,jakkolwiek wedle niektórych, załatwić ten temat byłoby skierować twarz ku niebu [tj. wykazać się dozą arogancji, rzucając wyzwanie kręgom ludzi dzierżących władzę - przyp. M. W.], jednak, skoro dla dojścia do prawdy dyskutuje się także o zagadnieniach nieba, przystępuję do rozplątania tej sprawy"1. I realizuje ten zamiar, jak czynić powinniśmy i my wszyscy, bo jeśli rzeczy dotyczące sfer niebieskich mogą stać się przedmiotem krytycznych rozważań, to z pewnością mogą być nim również rzeczy ziemskie. A uprawnienia ludzi dzierżących władzę to zawsze jedna z pierwszych rzeczy, które powinny zostać poddane tego rodzaju rozważaniom.

Wraz z Włodkowicem będę zajmował się głównie jus ad bellum, tj. decyzją o wszczęciu wojny, a nie sposobami prowadzenia wojny. Ale chcę zaznaczyć, że w sprawie wzajemnych relacji między kwestiami związanymi z ad bellum i in bello, Włodkowic zdaje się stać po stronie zwolenników współczesnych rewizjonistycznych teorii wojny sprawiedliwej - jest przeciwny zasadzie „moralnej równości” żołnierzy, której bronię od wielu lat. Utrzymuje, że żołnierze walczący w wojnach mających na celu podbój lub rabunek, bądź też stawiający aktywny opór bojownikom słusznej sprawy, nie mają prawa walczyć i nie mogą żądać przyznania sobie praw kombatantów

1 P. Włodkowic, Ad aperiendam, w: Dzieła wybrane Pawła Włodkowica, red. L. Ehrlich, vol. I, Warszawa 1968, 227. 
wojennych; są oni grzesznikami (powiedzielibyśmy dzisiaj: zbrodniarzami wojennymi). „Sprawiedliwie atakującemu nie może bez grzechu opierać się atakowany”2. Czy też w innym fragmencie: „Ci, którzy bez skruchy giną popierając (...) niedozwoloną wojnę są synami gniewu i należy słusznie sądzić, że dzielą los potępionych”’ Innymi słowy, wojna niesprawiedliwa to zbrodnia ludzi, którzy biorą w niej udział, choć Włodkowic czyni w tej kwestii pewne ustępstwa na rzecz zwykłych żołnierzy (mniejsze ustępstwa na rzecz „rycerzy”), którzy wykonują rozkazy swoich suwerenów. Tak więc współczesny rewizjonizm można odczytywać jako powrót do XV wieku. Zawsze uważałem, że jest to doktryna kościelna.

\section{POWRÓT DO DEBATY NA TEMAT ŚWIĘTEJ WOJNY}

Jednakże w odniesieniu do ius ad bellum możemy się wiele nauczyć od piętnastowiecznych uczonych-scholastyków - choć, jak będę utrzymywać, nie ze względu na ich lojalność względem doktryny Kościoła katolickiego. Włodkowic zwraca naszą uwagę w sposób szczególny, ponieważ jego wywody nie mają jedynie charakteru scholastycznego, czy też - jeśli można tak to ująć - akademickiego, ale są bardzo praktyczne - skierowane przeciwko grupie wojowników noszących określone imię. Włodkowic nazywa ich „Krzyżakami”, będę ich tak najczęściej określał również ja. Pełna nazwa ich zgromadzenia to „Zakon Szpitala Najświętszej Marii Panny Domu Niemieckiego w Jerozolimie”. Znani są też jako „Zakon Niemiecki”. Walczyli na ziemiach położonych na północ i wschód od Polski, przeciwko plemionom pogańskim, czyniąc to $\mathrm{w}$ imię Boga. Brali udział w świętej wojnie, ale czy była to wojna sprawiedliwa?

Teoria wojny sprawiedliwej została stworzona jako koncepcja katolicka. Każda cywilizacja i każda religia ma swoje reguły dotyczące

2 P. Włodkowic, Opinio Ostiensis, w: Dzieła wybrane Pawła Włodkowica, dz. cyt., 134.

3 P. Włodkowic, Saevientibus, w: Dzieła wybrane Pawła Włodkowica, dz. cyt., 62. 
wojny, określające czas oraz sposób walki, ale, o ile wiem, nikt inny nie wypracował systematycznej teorii. Pełny rozwój tej teorii ma miejsce w późnym średniowieczu, a zajmujący się nią myśliciele operują w spornym, czasem amorficznym, obszarze pomiędzy chrześcijańskim pacyfizmem a doktryną świętej wojny. Krytyka pacyfizmu nie odgrywa znaczącej roli w pismach powstałych w XV wieku, nie stanowi też głównego wątku rozważań Włodkowica, centralnym zagadnieniem w jego tekstach jest natomiast krytyka świętej wojny. Kiedyś sądziłem, że ostateczne odrzucenie świętej wojny nastąpiło w pismach hiszpańskich dominikanów z XVI wieku, zajmujących się podbojem obu Ameryk, momentami przeciwstawiających się temu podbojowi. Myliłem się - miało ono miejsce co najmniej sto lat wcześniej, w sprzeciwie wobec wojen zakonu krzyżackiego. A może jeszcze wcześniej: Włodkowic cytuje wielu myślicieli (m.in. wielokrotnie papieża Innocentego IV) z poprzednich wieków. Być może specyfiką przedstawianej przez niego krytyki świętej wojny jest jedynie jej wyrazistość: ma on na uwadze określoną grupę bojowników świętej sprawy i jest jasne, że czuje do nich odrazę. Nie mają prawa działać w imieniu Boga, bo Bóg nie zezwala na walkę z "spokojnym narodem niewiernych"4 a co może ważniejsze, natura i prawo naturalne zabraniają takich wojen. Pobożność Krzyżaków jest obłudna; prawdziwym motywem ich wojen, pisze Włodkowic, jest „żądza panowania”.

Stanowisko Włodkowica zostaje wyrażone w sposób dobitny: „Z tego wynika konkluzja”, pisze, „o błędzie, którego w żaden sposób nie wolno tolerować, mianowicie że chrześcijanie gromadzą się (...) celem napadania niewiernych, wskutek tego, że są niewiernymi (...)

4 P. Włodkowic, Opinio Ostiensis, dz. cyt., 117. Zastanawiam się, czy Włodkowic ma tu na myśli opowieść zamieszczoną w rozdz. 18 Księgi Sędziów, w której Danowie atakują Kananejczyków żyjących wokół Lajisz: „(...) przybyli do Lajisz, do ludu spokojnego i ufnego. Ludność wycięli ostrzem miecza, a miasto zniszczyli ogniem. Nie było nikogo, kto by ich ratował". Sdz 18, 27-31 (http://www.biblijni.pl/Sdz,18,27-31, dostęp: 18 września 2017).

5 P. Włodkowic, Opinio Ostiensis, dz. cyt., 132. 
w celu szerzenia wiary chrześcijańskiej (...)”. Wniosek ten został poddany dyskusji na soborze w Konstancji, mimo to jednak wydaje się, że okazał się rozstrzygający. Wraz z argumentami myślicieli takich jak Francisco de Vitoria w następnym stuleciu, zakończył on w gruncie rzeczy spory o świętą wojnę wśród teoretyków wojny sprawiedliwej związanych z Kościołem katolickim, a następnie, w sposób jeszcze bardziej jednoznaczny, wśród teoretyków prawa międzynarodowego, takich jak Alberico Gentili i Hugo Grotius, którzy dokonali adaptacji teorii wojny sprawiedliwej i przekształcili ją w prawo świeckie. W XVI i XVII w. pojawiło się jeszcze kilku obrońców świętej wojny wśród pisarzy protestanckich i purytańskich, i doszło do szeregu krwawych epizodów wojennych noszących charakter walki religijnej, jednakże w obrębie tradycyjnej teorii wojny sprawiedliwej spór był ostatecznie zakończony.

Od wczesnego okresu nowożytnego aż do czasów współczesnych wojna była tematem świeckim - szczególnie w XIX i XX wieku, kiedy powszechna stała się wiara $\mathrm{w}$ postęp sekularyzacji, nieuchronny triumf nauki i rozumu. Kwestią kluczową w tych latach, kwestią jedyną, była odpowiedź na pytanie: Jakie cele świeckie mogą usprawiedliwiać wojnę? Vitoria orzekł: jedynie „doznana krzywda”. Samoobrona przed krzywdą możliwą była usprawiedliwieniem podstawowym i oczywistym, ale co z prewencją i uderzeniem wyprzedzającym, gdy krzywdy nie zostały jeszcze „odniesione”, jednak wydają się w sposób wyraźny rysować na horyzoncie, czy wręcz jawią się jako bezpośrednie zagrożenie? Co z pomocą poszkodowanemu sojusznikowi, czy też ościennemu państwu zagrożonemu krzywdą? A co z interwencją w bliskim bądź odległym państwie, mającą na celu powstrzymanie przeprowadzanej tam rzezi ludności cywilnej? A co Z wojną przeciw tyranii - czy też wojną zmierzającą do „uczynienia świata bezpiecznym dla funkcjonowania demokracji”? Wszystkie te wojny były wojnami możliwymi, mogły stawać się tematem sporów,

6 P. Włodkowic, Saevientibus, dz. cyt., 61. 
ale wojna święta była niemożliwa i nigdy nie była dyskutowana, stanowiła temat rozważań czysto historycznych.

Sytuacja ta uległa obecnie zmianie: chrześcijańskie krucjaty, święte wojny średniowiecza, powróciły w postaci islamskiego dżihadu. Sekularyzacja nie wydaje się już nieunikniona, a w wielu częściach świata nawet prawdopodobna. I tak dorobek Włodkowica i wszystkich myślicieli jemu współczesnych, jak również jego poprzedników, staje się ponownie niezwykle istotny; argumenty, które były dla nich kluczowe i aktualne, są kluczowe i aktualne również dla nas. Zamierzam opisać niektóre z klasycznych ujęć wojny świętej, wypracowanych w przeszłości i współcześnie, w historii chrześcijaństwa i w dzisiejszym islamie, a następnie rozważyć argumenty przeciwko tego rodzaju wojnie. Nazywam je argumentami radykalnymi, ponieważ odmawiają one religii jakiejkolwiek roli w odniesieniu do ius ad bellum, zarówno przy podejmowaniu decyzji o wszczęciu wojny, jak i przy formułowaniu argumentów w obronie tej decyzji.

\section{ARGUMENTY UCZESTNIKÓW ŚWIĘTEJ WOJNY}

Uczestnicy świętej wojny utrzymują w pierwszym rzędzie, że Bóg ma po prostu władzę nad całą ziemią, a zadaniem jego obrońców jest urzeczywistnienie jego panowania - wszędzie. Stąd niewierni i heretycy nie mają prawa rządzić nigdzie i gdziekolwiek rządzą, muszą zostać pokonani i obaleni. Włodkowic, jak zobaczymy, przeciwstawia się temu twierdzeniu, ale jest oczywiste, że ludzie, z którymi toczy spór, wśród nich głównie Krzyżacy, uznają je za prawdziwe. W dzisiejszym islamie podobne tezy są w sposób zdecydowany aprobowane przez wojowników dżihadu oraz ich religijnych przywódców, z drugiej zaś strony kwestionowane przez islamskich odpowiedników Pawła Włodkowica. Zadaniem dżihadu, pisze Yusuf al-Uyayri, jeden z głównych teoretyków al-Kaidy, jest „usunięcie zepsucia $\mathrm{z}$ powierzchni ziemi i rozszerzenie zasięgu oddziaływania religii muzułmańskiej na cały świat. Obowiązek 
prowadzenia dżihadu przestanie być obowiązkiem dopiero wtedy, gdy zrealizowany zostanie prawdziwy cel dżihadu, tj. pełna kontrola nad całą ziemią"7.

Istnieją również mniej ambitne - powinniśmy może użyć określenia 'pośrednie' - cele uzasadniające świętą wojnę - takie jak ponowny podbój ziem, na których rządzili niegdyś namiestnicy Boga. Nawet Włodkowic broni hiszpańskiej rekonkwisty: „Natomiast wojna Hiszpanów przeciw Saracenom jest sprawiedliwa (...) dlatego że jest dla odzyskania ziem chrześcijańskich i [takich], na których

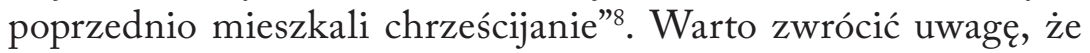
podobny argument jest dziś stosowany przez wielu dżihadystów, ponieważ Hiszpania była również „dawniej zamieszkana” przez muzułmanów. W książce zatytułowanej Why Are We Waging Jihad? (Dlaczego prowadzimy dżihad?), opublikowanej przez islamską organizację Lashkar-e-Ta’iba, Hiszpania znajduje się na liście ziem, które muszą zostać odzyskane: „Muzułmanie rządzili Andaluzją przez 800 lat (...) Chrześcijanie rządzą [tam] teraz, a zatem musimy ten obszar od nich wyrwać [inne kraje na liście to „cały obszar Indii” Bułgaria, Węgry, Cypr, Sycylia, Etiopia, rosyjski i chiński Turkiestan]" ${ }^{\prime}$. Cel nadrzędny dla średniowiecznych chrześcijan stanowiło natomiast prawdopodobnie odzyskanie Ziemi Świętej i Jerozolimy, gdzie Jezus żył i umarł - Włodkowic popiera te usiłowania, choć w $1415 \mathrm{r}$. nie była to kwestia szczególnie pilna. Ma ona również wielkie znaczenie dla współczesnych wojowników dżihadu. Zwróćmy uwagę na następujące wyjaśnienie zwrotu Dar al-Harb (obszar wojny), który używany jest dla określenia wszystkich ziem wykraczających poza obszar o dominującej roli islamu: „Istnieje różnica między tymi krajami, które są uważane za Dar al-Harb

7 Cyt. za.: R. Ali, H. Stuart, A Guide to Refuting Jihadism Critiquing Radical Islamist Claims to Theological Authenticity, London 2014, 49.

8 P. Włodkowic, Saevientibus, dz. cyt., 63.

9 Cyt. za.: R. Ali, H. Stuart, dz. cyt., 25. 
filan (rzeczywisty obszar wojny), jak w przypadku państwa Izrael, zajmującego ziemię muzułmańską, oraz tymi, które są uważane za Dar al-Harb hukman (potencjalny obszar wojny), obejmujący państwa, które nie zajmują ziemi muzułmańskiej”10.

Jednak w wielu argumentach wspierających świętą wojnę władza i jej zasięg ustępują pierwszeństwa pragnieniu wybawienia niewiernych i heretyków od wiecznego potępienia. Nawrócenie niewiernych i przywrócenie heretyków do prawdziwej wiary można by uznać za religijną wersję interwencji humanitarnej - nawet jeśli nie uratuje ona mężczyzn i kobiet, którzy są nawracani siłą („służby wymuszone nie podobają się Bogu"11, pisze Włodkowic), uratuje dzieci nawróconych, które przyjmą naukę chrześcijańską w taki sam sposób jak inni chrześcijanie. XII-wieczny perski komentator Koranu cytuje werset „kto chce, niech wierzy, a kto nie chce, niech nie wierzy!"12 i twierdzi, że w związku z jego treścią przymus i przemoc są "niedozwolone” ${ }^{\text {13. }}$. Jednak Krzyżacy w XV w. byli - tak jak wojownicy dżihadu są dzisiajaktywnie zaangażowani w szerzenie wiary, często z wykorzystaniem bardzo okrutnych środków przymusu, przy czym jedna i druga grupa uważała (uważa), że jest zaangażowana w przedsięwzięcie mające na celu zbawienie dusz. Zastanawiam się, czy ktoś, kto potępia tę wersję zbawienia, jak Włodkowic i wspomniany wyżej perski komentator Koranu, może naprawdę uważać, że niewierni, którym zezwala się na „odrzucenie wiary”, zostaną następnie odrzuceni przez Boga i skazani na życie pozagrobowe w straszliwym cierpieniu. Rozpowszechnianie wiary, nawracanie pogan, wydaje mi się najsilniejszym argumentem za wojnami motywowanymi religijnie. Czy argument ten można podważyć bez wychodzenia poza sferę doktryny religijnej - bądź też bez powoływania się na Boga bardziej miłosiernego niż Bóg, którego

10 Cyt. za.: R. Ali, H. Stuart, dz. cyt., 41.

11 P. Włodkowic, Saevientibus, dz. cyt., 60.

12 J. Bielawski, Tłumaczenie znaczenia Świętego Koranu, 18:29, http://www.planetaislam. com/koran_bielawski.html, [dostęp: 7 września 2017].

13 R. Ali, H. Stuart, dz. cyt., 54. 
uznaje każdy z uczestników świętej wojny, a także wielu teologów, zarówno chrześcijan i muzułmanów? Ktoś, kto wierzy w predestynację, mógłby po prostu utrzymywać, że zbawienie jest sprawą Boga i nikogo innego; ludzie nie mają w tej kwestii nic do powiedzenia. Ale pogląd ten z pewnością nie odzwierciedlał stanowiska katolickich uczonych-scholastyków okresu średniowiecza i wątpię, czy jest to pogląd ich muzułmańskich odpowiedników.

Zanim przystąpię do obrony tezy, w myśl której argumenty przeciwko stosowaniu przymusu najlepiej formułować z świeckiego punktu widzenia, postaram się uzupełnić swój opis różnych rodzajów świętych wojen oraz ich przyczyn - czy też lepiej - przy uwzględnieniu przedstawionych niżej przypadków - ich pozornych przyczyn. Częstym uzasadnieniem wojny jest twierdzenie, że chrześcijanie (lub muzułmanie) są w krajach rządzonych przez niewiernych prześladowani; innym uzasadnieniem może być odmowa ze strony niewiernych władców uznania prawa do głoszenia na terenie ich krajów chrześcijańskiego (lub muzułmańskiego) orędzia wiary. Włodkowic opowiada się za obydwoma rodzajami uzasadnień, choć bez szczególnego nacisku, może dlatego, że wie, jak często stawały się one pretekstami do podboju. Niemniej występuje w obronie jurysdykcji jedynie „pokojowo nastawionych” niewiernych i twierdzi, że „papież może nakazać niewiernym, aby dopuszczali kaznodziejów Ewangelii na swoje ziemie (...) [i] jeśli zabraniają kaznodziejom głosić [że wszelkie stworzenie rozumne zostało stworzone dla chwalenia Boga], grzeszą i dlatego muszą być ukarani”"14. W podobny sposób wielu autorów muzułmańskich utrzymuje, że gdziekolwiek dochodzi do nękania lub prześladowania muzułman, dżihad jest uzasadniony, a nawet konieczny.

Wreszcie Włodkowic twierdzi, podążając za opinią wielu innych autorów, że „papież może karać niewiernych, czczących bałwany; naturalne jest bowiem czcić jednego jedynego Boga, Stwórcę, a nie

14 P. Włodkowic, Saevientibus, dz. cyt., 35. 
[jego] stworzenia" ${ }^{15}$. W myśl tego argumentu nawrócenie się na chrześcijaństwo nie jest konieczne, konieczna jest jedynie rezygnacja z politeizmu. Nie zetknąłem się z ściśle analogicznym argumentem w islamie, chociaż tolerowanie chrześcijan i Żydów, „ludzi Księgi”, może odzwierciedlać nieco podobny pogląd, a mianowicie że od zwolenników doktrynalnie niepełnego czy też niepełnowartościowego monoteizmu nie powinno się wymagać przyjęcia prawdziwej wiary. Autorzy żydowscy wypracowali ten sam argument, choć jedynie w odniesieniu do przymusu obowiązującego w danym kraju, a nie w odniesieniu do wojny: żydowski król może wymagać od wszystkich swoich poddanych oddawania czci jednemu Bogu, ale nie może wymagać od nich nawrócenia się na judaizm. Król egzekwuje „Prawa Noachidów”, które są czymś podobnym do tego, co scholastycy nazywają prawem naturalnym, bądź też stanowią jego wersję judaistyczną. Ale nie sądzę, by jakieś wojny były kiedykolwiek toczone przy tak ograniczonym celu działań zbrojnych - aby nawrócić pogan na monoteizm wolny od obciążeń związanych z prawdziwą doktryną religijną. Częściej w ślad za wojownikami Boga podążają gorliwie jego kapłani.

\section{4. (RELIGIJNA) OBRONA ROZUMU NATURALNEGO}

Najważniejsze z tych uzasadnień świętej wojny - urzeczywistnianie boskiego panowania nad całym światem oraz szerzenie wiary zostają przez Włodkowica w sposób jednoznaczny odrzucone, tak jak odrzucone zostają przez wielu muzułmańskich autorów o podobnych zapatrywaniach - przez Islamskich Scholastyków. Podstawą religijną tego odrzucenia jest w obu przypadkach opis stworzenia, a nie treść objawienia, a odwołanie się do stworzenia okazuje się metodą argumentacji z natury stworzonego przez Boga świata - bez dalszego odnoszenia się do Boga. Oto pierwszy argument, który chcę

15 Tamże, 29. 
przedstawić; jest to argument dość powszechny, choć nie zawsze zostaje uwypuklony w sposób, na który zasługuje. Sprzeciw wobec świętej wojny jest zasadniczo przedsięwzięciem świeckim, nawet jeśli jest to przedsięwzięcie realizowane przez autorów religijnych. Pacyfizmu można bronić poprzez odwołanie się do objawienia, podobnie ma się rzecz z obroną świętej wojny. Ale twierdzenie, że wojna musi mieć i może mieć wyłącznie cel doczesny (ochrona życia i wolności czy też suwerenności i integralności terytorialnej danego kraju), wymaga obrony w kategoriach doczesnych. Włodkowic cytuje Tomasza z Akwinu, wypracowując, jak sądzę, kluczowe podłoże wszelkich argumentów przeciwko świętej wojnie przedstawianych przez autorów religijnych: „[W]ładztwo i przełożeństwo zaprowadzone zostały na mocy prawa ludzkiego, mianowicie na mocy prawa narodów, a odróżnienie wiernych i niewiernych jest na mocy prawa Boskiego. Prawo zaś Boskie, prawo, które jest z łaski, nie zabiera prawa ludzkiego, które jest z naturalnego rozumu"16.

Posługując się współczesnym żargonem politycznym, można by powiedzieć, że Paweł Włodkowic, jak również Akwinata, byli „umiarkowanymi” chrześcijanami - zwracamy się zatem w kierunku „umiarkowanych” muzułmanów, którzy mogliby się przeciwstawić wojownikom dżihadu. Ale nie sądzę, by sedno sprawy leżało w umiarkowaniu. Nie ma też sensu nawoływanie do przeprowadzenia muzułmańskiej „reformacji”, jak czyni wielu współczesnych krytyków islamizmu. Ostatecznie Protestancka Reformacja przyniosła Europie 100 lat walki religijnej. To, co jest konieczne, to obrona naturalnego rozumu, która okazuje się zgodna z głębokim zaangażowaniem religijnym. Powiedziałbym nieomal, że Włodkowic był zagorzałym obrońcą rozumu przeciw religijnej „zawziętości” Krzyżaków ${ }^{17}$.

Włodkowic twierdzi, że niewierni posiadają wszelkie prawa do sprawowania władzy i posiadania własności - zgodnie z prawem

16 Tamże, 136.

17 Tamże, 4. 
cywilnym, kanonicznym, prawem naturalnym i prawem boskim. Przykładami prawa boskiego, które podaje, są przykazania zapisane w Księdze Wyjścia: „Nie będziesz zabijał” i „Nie będziesz kradł”. Ale te dwie - a także wszystkie pozostałe - reguły moralne zaczerpnięte $\mathrm{z}$ hebrajskiej Biblii są powszechnie uważane za odtworzenie prawa naturalnego. „Nawet gdyby nie zostało ono zapisane - mówi Talmud - to powinno było zostać zapisane". Co oznacza: gdyby Bóg nie spisał dwóch tablic na górze Synaj, ich treść wynaleźlibyśmy dla siebie sami. Ten sam pogląd wyrażony zostaje w sposób zwięzły przez Włodkowica, gdy opisuje on prawo naturalne, powołując się na tekst biblijny: „Co chcesz dla siebie, czyń drugiemu”. A cały jego argument zostaje ujęty skrótowo za pomocą innego fragmentu Biblii, uznanego za jedną z prawd dostępnych dla rozumu. Każda próba pozbawienia niewiernych władzy lub majątku „bez sprawiedliwej przyczyny, nie godzi z sobą miłości bliźniego (...), bliźnimi zaś naszymi są wedle Prawdy zarówno wierni jak niewierni, bez różnicy"18. Bóg jest jedynie użytecznym dodatkiem do tego rozumowania, i w gruncie rzeczy nie jest on dla niego istotny - choć, jak już wcześniej zaznaczyłem, odwołanie się do prawa naturalnego jest również odwołaniem się do stworzenia przez Boga świata przyrody oraz natury ludzkiej.

Boskie dzieło stworzenia spełnia w tych wywodach rolę podobną do roli, którą odgrywa stan natury w późniejszej teorii politycznej: opisuje czas, w którym nie było ani Żydów, ani chrześcijan, ani muzułmanów, ani pogan - tylko ludzie. „[W] istocie rzeczy ziemia i wszystko co na niej jest, [jest] Boga, ale sam Bóg to wszystko poddał istocie rozumnej, dla której wszystko stworzył" ${ }^{19}$. Te rozumne istoty podzieliły świat między siebie, w myśl rozpoznanej w trybie naturalnym zasady, zgodnie z którą „,co wprzód zajęte przez jednego, nie wolno zajmować drugiemu"20. Włodkowic, podążając w tej części

18 Tamże, 59.

19 Tamże, 12.

20 Tamże, 12. 
swych wywodów głównie za Innocentym IV, przedstawia w zarysie teorię pochodzenia własności i władzy. „[Z]ostały one utworzone”, jak pisze, ,nie tylko dla wiernych, ale dla każdej rozumnej istoty" ${ }^{21}$. Stąd niewiernych nie wolno atakować ani wywłaszczać. $Z$ pewnością nie wolno ich zabijać - powody tego zakazu zostały określone w sposób przejrzysty przez muzułmańskiego badacza prawa już w XIII wieku: „Zaprawdę, podstawową zasadą jest umożliwienie życia niewiernym i ich akceptacja. Bóg nie miał zamiaru zniszczyć stworzenia! Nie stworzył ich też po to, by można ich było zabijać." Brzmi to jak argument religijny, ale tak naprawdę nim nie jest. Stworzenie jest dla istot stworzonych i to ich rozum, nasz rozum, sprawuje rządy nad światem - bądź też powinien sprawować rządy nad pożądaniem, zaciekłością, okrucieństwem i chciwością, które są również częścią Boskiego stworzenia.

Teoria wojny sprawiedliwej jest dziełem tych właśnie rozumnych istot, twoim i moim, jeśli możemy rościć sobie prawo do tego tytułu. Krytyka świętej wojny jest dziełem rozumu. Sądzę, że wynika ona również z pewnej dozy sceptycyzmu co do [rzekomego] zaangażowania Boga w przedsięwzięcia o charakterze politycznym czy militarnym. Włodkowic pisze, że istnieją trzy sposoby zdobywania władzy: przez otrzymanie jej z bożej łaski, „przez zgodę tych, którzy są rządzeni" i przez przemoc ${ }^{22}$. Papież rządzi za sprawą bożej łaski, ale, według Włodkowica, nie może on autoryzować podbojów dokonywanych przez Krzyżaków, nawet jeśli chciałby to uczynić. W odniesieniu do panowania politycznego, w grę wchodzi jedynie drugi i trzeci sposób. Poganie zamieszkujący ziemie wschodnie nie zgadzają się na rządy Krzyżaków; stąd Krzyżacy sprawują swe rządy wyłącznie poprzez przemoc, która jest „tyranią”. Jedynie zgoda poddanych legitymizuje władzę - wniosek ten uważam za odkrycie rozumu naturalnego.

21 Tamże, 13.

22 Tamże, 56-7. 
To właśnie ów naturalny rozum powinniśmy włączyć w walkę z radykalizmem dżihadu. Jestem głęboko przekonany, że powinniśmy zarazem angażować się $\mathrm{w}$ dialog $\mathrm{z}$ islamskimi tekstami, tekstami religijnymi. Te, które przytaczam w tym artykule, są zebrane w niewielkich rozmiarów książce zatytułowanej $A$ Guide to Refuting Jihadism: Critiquing Radical Islamist Claims to Theological Authenticity (Jak odrzucić dżihad: krytyka roszczeń radyklanego islamu do teologicznej autentyczności) ${ }^{23}$. Jest to książka bardzo pomocna, ale prawdopodobnie odmawianie religijnej ,autentyczności” bojownikom dżihadu nie jest rzeczą słuszną; oni również posiadają umiejętność cytowania tekstów; nie są bardziej nieautentyczni niż chrześcijańscy krzyżowcy, czy też Krzyżacy Włodkowica. Ale nie mają racji. W wyrażanym przez nas sprzeciwie wobec ich poglądów naszymi sprzymierzeńcami są muzułmańscy teologowie, których nazwałem Islamskimi Scholastykami. Powinniśmy uważnie badać ich dzieła i czynić to zawsze z należytym szacunkiem. Ale powinniśmy również zauważyć, że opowiedzenie się przez nich po stronie Boskiego dzieła stworzenia oraz po stronie Jego stworzeń jest - podobnie jak w przypadku analogicznego stanowiska scholastyków katolickich - w sposób radykalny racjonalne. Głoszona przez nich wykładnia prawa naturalnego jest adresowana do wszystkich ludzi, do wszystkich rozumnych stworzeń, wierzących i niewierzących - jest ona zarazem dla nich wszystkich w pełni dostępna. Cokolwiek piszemy, powinno posiadać tak samo szeroki zasięg odbiorców i powinno być w takim samym stopniu dostępne.

Myślę czasem, że ci z nas, którzy wspierają liberalne rozwiązania polityczne, opowiadają się za wielokulturowością i poprawnością polityczną (nawet jeśli towarzyszy temu zawsze doza ironicznego

23 Więcej szczegółów na temat muzułmańskich teorii dotyczących wojny znaleźć można w: J. Kelsay, Islam and War: A Study in Comparative Ethics, Westminster Press, Louisville Kentucky 1993. Natomiast analizę rozwoju chrześcijańskiej doktryny wojny sprawiedliwej prezentuje James T. Johnson: J.T. Johnson, Ideology, Reason, and the Limitation of War: Religious and Secular Concepts, 1200-1740, Princeton University Press, Princeton 1975. 
dystansu), są momentami zbyt nieśmiali w swoim sprzeciwie wobec religijnego ekstremizmu. Obawiamy się, że nie jesteśmy go w stanie „pojąc”, że nie rozumiemy ekstremistów, i że nasza krytyka skierowana pod ich adresem może być obraźliwa dla religijnie zaangażowanych mężczyzn i kobiet, których chcielibyśmy skłonić do przejścia na naszą stronę. Moglibyśmy być bardziej skuteczni w pozyskiwaniu tego rodzaju sojuszników, gdybyśmy byli bardziej bojowo nastawieni w obronie liberalnych wartości, które, jak starałem się pokazać, są również wartościami dla wielu myślicieli religijnych. Ponownie mam tu na myśli nie „umiarkowanych” myślicieli religijnych, ale autorów gotowych - tak jak powinniśmy być i my sami - „skierować twarz ku niebu".

\section{PRZECIW ZWOLENNIKOM KRUCJAT ŚWIECKICH}

Poprzedni akapit brzmi jak podsumowanie, ale jeszcze nie skończyłem. Chcę teraz przetestować przedstawiony wyżej argument, stawiając pytanie, czy ma on również zastosowanie do uzasadnień operacji wojennych, których cele ugruntowane są nie w teologii, ale w ideologii świeckiej. Istnieją bowiem argumenty świeckie, które w sposób ścisły odpowiadają twierdzeniu, że dobrze jest nawracać niewiernych. Rozważmy zatem następujący przypadek analogiczny do wojen krzyżackich toczonych w XV wieku. Włodkowic twierdzi, że piętnastowieczni Krzyżacy nie mogli w sposób sprawiedliwy rządzić plemionami pogańskimi zamieszkującymi obszary wschodniej Europy, ponieważ mieszkańcy tych ziem nie wyrazili zgody na ich rządy. Jest jednak mało prawdopodobne, by ludzie ci kiedykolwiek wyrażali zgodę na rządy swoich pogańskich wodzów i królów. Wyobraźmy sobie więc, że ziemie wschodnie zostają zaatakowane przez Zakon Rycerzy Demokratycznych, występujących w obronie prawa naturalnego, zgodnie z którym legalna władza może być oparta wyłącznie o jej uprzednią akceptację przez rządzonych, oraz obiecujących, że jeśli wygrają rozpoczętą przez siebie wojnę, 
zorganizują wolne wybory. Ich celem nie jest nawracanie pokonanych, ale zmiana systemu władzy; nie są wyznawcami jedynej prawdziwej religii, a raczej rzecznikami jedynej moralnie uzasadnionej teorii polityki. Jeśli chcecie historycznych przykładów tego rodzaju zdarzeń, pomyślcie o Armii Czerwonej, zmierzającej w kierunku Warszawy w 1920 roku, aby zaprowadzić w Polsce komunizm, bądź też o armii amerykańskiej, maszerującej na Bagdad w 2003 roku, aby wprowadzić w Iraku system demokratyczny. I oto druga teza tego artykułu: wojny tego rodzaju, podobnie jak wojny piętnastowiecznych Krzyżaków, są wojnami niesprawiedliwymi i są nimi z powodów w sposób znaczący analogicznych do tych, które przedstawia Paweł Włodkowic.

Muszę jasno określić zakres owej drugiej tezy. Nie chcę wykluczać ani potępiać wojen noszących cechy interwencji humanitarnych. Gdyby pogańscy władcy z rozpatrywanego przeze mnie przykładu analogicznego do piętnastowiecznych wojen krzyżackich przeprowadzali masowe mordy, dopuszczali się gwałtów i stosowali terror, wojna z nimi, nawet wtedy, gdyby była prowadzona przez wojowników nieuznających jedynej słusznej teorii polityki, byłaby z pewnością usprawiedliwiona. W następstwie takiej wojny rządzący owym krajem zbrodniarze musieliby zostać odsunięci od władzy, i byłoby dobrze, gdyby zostali zastąpieni przez rząd, który uzyskałby wcześniej akceptację mieszkańców tego kraju. Oczywiście tego rodzaju usprawiedliwienie wojny może być również pretekstem - jak w przypadku oświadczeń hiszpańskich zdobywców Ameryki Środkowej z XVI wieku, że walczyli, aby zakończyć rytualne ofiary z dziewic składane bóstwom pogańskim (oraz innym naruszeniom prawa naturalnego). Nie trzeba dodawać, że po odniesieniu zwycięstwa nie sprawowali oni rządów za zgodą rdzennych Amerykanów. Nie chcę też wykluczać zmiany władzy po pokonaniu agresywnych reżimów wojskowych, jak miało to miejsce po II wojnie światowej w przypadku Niemiec i Japonii. Chciałbym natomiast wykluczyć wojny przeciwko autokratom i oligarchom, jak również przeciw rządom starszyzny 
religijnej i rad mędrców, którzy ze swoimi poddanymi i sąsiadami współżyją „spokojnie” i „pokojowo”24.

Jedyna słuszna teoria polityki nie uprawnia tych, którzy ją poznali, do rządzenia światem, czy też do ustanawiania wszędzie jedynego słusznego systemu politycznego, podobnie jak jedyna prawdziwa wiara nie uprawnia jej wyznawców do sprawowania powszechnych rządów. Argument ten w formie religijnej brzmiałby w sposób następujący: Bóg-Stworzyciel stworzył mężczyzn i kobiety, obdarzając z kolei ich wszystkich zdolnością do tworzenia wielu różnych systemów politycznych oraz sposobów życia - jak również do nazywania ich dobrymi. Ten sam argument w postaci świeckiej otrzymałby następujące brzmienie: natura ludzka niesie ze sobą dające się racjonalnie uzasadnić prawo do kształtowania społeczeństw i wspólnot politycznych na wiele różnych sposobów oraz do życia w pokoju w ich obrębie. Nieobecność w takich krajach jakiejkolwiek znaczącej opozycji, czy też ognisk buntu lub rewolucji, powinniśmy traktować jako wystarczającą oznakę przyzwolenia ich mieszkańców na sprawowane nad nimi rządy, a przynajmniej jako znak swoistego kulturowego „dopasowania” tych społeczeństw do własnych systemów politycznych - równoznaczny z zakazem interwencji z zewnątrz. Nie jest to oczywiście zakaz krytyki ideologicznej. Dla przykładu, rządy rady mędrców religijnych nie wydają mi się dobrym systemem politycznym, i jestem w pełni gotów, by wyjaśnić swoje stanowisko, ale jakiekolwiek wyjaśnienia przedłożę, nie mogą być one nigdy powodem do wszczynania wojny przeciwko owym mędrcom. Tego rodzaju atak - parafrazuję tutaj Włodkowica - „bez sprawiedliwej przyczyny, nie godzi z sobą miłości bliźniego (...), bliźnimi zaś naszymi są wedle Prawdy zarówno demokraci jak i nie-demokraci,

24 Powyższy wywód jest, w myśl moich zamierzeń, spójny z tym, co napisałem wiele lat temu w Wojnach sprawiedliwych i niesprawiedliwych (M. Walzer, Wojny sprawiedliwe i niesprawiedliwe, tłum. M. Szczubiałka, Warszawa 2010; wyd. ang. Just and Unjust Wars, Basic Books, New York 1977). W trakcie pracy nad tą książką uczęszczałem do szkół wraz z katolickimi teoretykami wojny sprawiedliwej. 
bez różnicy”. Tak więc np. wojna z irańskimi ajatollahami nie byłaby wojną usprawiedliwioną - chyba że rozpoczęliby oni kampanię masowych mordów skierowaną przeciwko Kurdom, zoroastrianom, bahaitom czy wyznawcom innych odłamów islamu, bądź też zaatakowali swoich sąsiadów.

Spróbujmy rozszerzyć nieco ten argument. Jak już wyżej wskazałem, krytyka autokratycznych i oligarchicznych reżimów jest całkowicie uzasadniona, może nawet konieczna. Czy należy żądać od przedstawicieli takich reżimów, by zezwalali na przyjazd do swoich krajów krytyków własnych rządów - tak jak, według Włodkowica, należy żądać od pogańskich władców, by zezwolili na głoszenie Ewangelii w ich krajach? Czy cenzura lub tłumienie krytyki usprawiedliwiają wojnę? Chcę powiedzieć wyraźnie, że nie, i uważam, że takiej samej odpowiedzi powinno się udzielić na pytanie pokrewne: Czy nękanie lub prześladowanie lokalnych demokratów - a więc zdarzenia mające miejsce w wielu autorytarnych reżymach, uzasadniają inwazję Rycerzy Demokracji? Odpowiedź znowu powinna być negatywna. Twierdzenia tego rodzaju były zbyt często pretekstem do wojen imperialnych. Zwykłemu („spokojnemu”) autorytaryzmowi powinno się przeciwstawiać ideologicznie, politycznie, dyplomatycznie - ale nie militarnie. Bowiem śmierć i zniszczenie to rezultaty działań wojskowych, które są znacznie bardziej prawdopodobne niż zaprowadzenie w danym kraju demokracji. W tym miejscu zacytuję Włodkowica bezpośrednio i pozostawię Czytelnikowi sformułowanie odpowiedniej współczesnej parafrazy: „[W]ierni Chrystusowi w celu pełnienia służby wojennej, wierząc, że oddają hołd Bogu, schodzą się tłumnie [do bitwy] i spokojny naród niewiernych z okazji szerzenia wiary katolickiej, jest okrutnie atakowany. Stąd wynikają zabójstwa (...) następują rabunki i nieskończone inne niegodziwości”25.

A zatem argument przeciwko Krzyżakom i wojownikom dżihadu stosuje się również do uczestników krucjat świeckich, którzy

25 P. Włodkowic, Saevientibus, dz. cyt., 3. 
są, jak sądzę, znacznie nam bliżsi, niż uczestnicy wczorajszych czy dzisiejszych krucjat religijnych. Jest to bardzo stary argument; był on przedstawiany wielokrotnie $\mathrm{w}$ dziejach ludzkości - często $\mathrm{z}$ wielką żarliwością i zapałem: a mianowicie, że zgodnie z rozumem naturalnym zwierzchnictwo polityczne należy do wszystkich ludzi; że wszyscy ludzie, bez względu na swe wierzenia (czy też, jak dodalibyśmy dzisiaj, na swoją rasę lub swoją płeć) mają prawo do wzięcia udziału w kształtowaniu różnorodnych form tegoż zwierzchnictwa; że przedsięwzięcie to przynosi w efekcie różne rezultaty; że wspólistnienie różnic, o ile ma pokojowy charakter, stanowi jedną z centralnych wartości ludzkich; i wreszcie, że jest bardziej prawdopodobne, iż dążenie do usunięcia tych różnic motywowane jest żądzą dominacji, niż miłością ludzkości. Choć wszystkie te konstatacje wynikają $\mathrm{w}$ istocie $\mathrm{z}$ rozumu naturalnego, nie są one oczywiste. Musimy ich bronić - raz jeszcze - z żarliwością i zapałem.

ttumaczenie z angielskiego: Adam Cebula

\section{BIBLIOGRAFIA}

Ali R., Stuart H., A Guide to Refuting Jihadism Critiquing Radical Islamist Claims to Theological Authenticity, The Henry Jackson Society, London 2014.

Włodkowic P., Ad Aperiendam, w: Pisma wybrane Pawta Wodkowica, t. 1, red. Ludwik Ehrlich, Instytut Wydawniczy PAX, Warszawa 1968, 144-259.

Włodkowic P., Opinio Ostiensis, w: Pisma wybrane Pawta Wodkowica, t. 1, red. Ludwik Ehrlich, Instytut Wydawniczy PAX, Warszawa 1968, 113-137.

Włodkowic P., Saevientibus, w: Pisma wybrane Pawta Wodkowica, t. 1, red. Ludwik Ehrlich, Instytut Wydawniczy PAX, Warszawa 1968, 1-98.

\section{JUST WAR AND HOLY WAR: AGAIN}

Abstract. This article describes the arguments of Paul Wladimiri, a 15th century Polish philosopher/theologian, about the justice of war (jus ad bellum). It defends his claim that natural reason sets limits on warfare and, specifically, bars holy wars, like the crusades of 
the Teutonic Knights - and, by extension, the wars of jihadist militants today. It also bars the ideological crusades of secular militants.

Keywords: just war theory, holy war and jihad, (un)justified intervention

Angielska wersja artykułu została opublikowana w marcu 2017 r. w 24 tomie (nr 1) belgijskiego czasopisma Ethical Perspectives: Michael Walzer, Just War and Holy war: Again, Ethical Perspectives 24(2017)1, 7-20.

Ethical Perspectives. A Quarterly Review - ISSN 1370-0049 - eiSSN 1783=1431

European Centre for Ethics, KU Leuven, Belgium

Wydawca: Peeters Publishers

Bondgenotenlaan 153, B-3000 Leuven, Belgium

walzer@ias.edu

Michael Walzer

Institute for Advanced Study

1 Einstein Drive, NJ 08540 Princeton, USA

DOI: 10.21697/spch.2017.53.3.01 